\title{
PREVALENCE OF OVERWEIGHT AND OBESITY AND ASSESSMENT OF LIPID PROFILE AND FASTING BLOOD GLUCOSE LEVELS AMONG FEMALE PREMEDICAL STUDENTS AT NNAMDI AZIKIWE UNIVERSITY, NNEWI CAMPUS, NIGERIA
}

\section{EMMANUEL IKECHUKWU ONWUBUYA ${ }^{1}$, NKIRUKA ROSE UKIBE ${ }^{2 *}$, OFIA ANYA KALU ${ }^{1}$, OBIAGELI FIDELIA EMELUMADU ${ }^{3}$, IFEOMA NWAMAKA MONAGO ${ }^{4}$, SOLOMON NWABUEZE UKIBE ${ }^{5}$}

\begin{abstract}
${ }^{1}$ Department of Internal Medicine, Faculty of Medicine, College of Health Sciences, Nnamdi Azikiwe University, Nnewi Campus, P.M. B 5025, Anambra State, Nigeria. ${ }^{2}$ Deparment of Medical, Laboratory Science, College of Health Sciences, Nnamdi Azikiwe University, Nnewi Campus, P. M. B 5025, Anambra State, Nigeria. ${ }^{3}$ Department of Community Medicine, Faculty of Medicine, College of Health Sciences, Nnamdi Azikiwe University, Nnewi Campus, P.M. B 5025, Anambra State, Nigeria. ${ }^{4}$ Department of Medicine, Federal Medical Center Oko, Anambra state, Nigeria.

${ }^{5}$ Department of Prosthesis and Orthotics, Federal University of Technology, Owerri, Imo State, Nigeria. Email: nr.ukibe@unizik.edu.ng
\end{abstract}

Received: 7 April 2018, Revised and Accepted: 11 May 2018

ABSTRACT

Objective: Obesity is a major public health issue and a significant risk factor for metabolic disorders. This prospective study was aimed at evaluating the prevalence of obesity, lipid profiles, and fasting blood glucose (FBG) among female premedical students of NAU, Nnewi Campus, Nigeria.

Methods: A total of 320 female premedical students aged 18-35 years were recruited. The participants were classified using Body mass index(BMI) as underweight (35), overweight (104), obese (26), and control (155). FBG and lipids were estimated using enzymatic methods. Obesity was assessed using BMI and waist circumference. Blood pressure (BP) was measured using accoson sphygmomanometer.

Results: The study observed $10.9 \%$ underweight, 32.5\% overweight, and $8.1 \%$ obesity. Underweight was higher among participants aged $18-23$ years (48.6\%), while overweight and obesity were more among participants aged $24-29$ years (57.7\% and 53.8\%). Central obesity was observed in 28.8\% of participants. BPs were higher in obese and overweight participants than in other groups. FBG was higher in obese and overweight participants than in other groups. The mean total cholesterol (TC) and low-density lipoprotein cholesterol (LDLC) were significantly higher in obese and overweight participants, while high-density lipoprotein cholesterol (HDLC) was significantly lower when compared to their corresponding values in underweight and control participants $(\mathrm{p}<0.05)$.

Conclusions: The study showed high prevalence of underweight, overweight, and obesity among the study population. The significantly higher levels of TC, LDLC, FBG, and elevated BP with significantly lower HDLC in overweight and obese participants compared to control suggests a possible risk of dyslipidemia, diabetes mellitus, and hypertension. The significant correlation between the lipid parameters, FBG, and anthropometric indices suggests high-risk cardiovascular disorders.

Keywords: Obesity, Overweight, Lipid indices, Fasting blood glucose, Female, Premedical students.

(C) 2018 The Authors. Published by Innovare Academic Sciences Pvt Ltd. This is an open access article under the CC BY license (http://creativecommons. org/licenses/by/4. 0/) DOI: http://dx.doi.org/10.22159/ajpcr.2018.v11i7.26500

\section{INTRODUCTION}

Obesity is a major non-communicable disease which has become a public health issue and future menace in developing countries, Nigeria inclusive. Young adult students of tertiary institutions are not left out. People are generally considered obese when their body mass index (BMI) is over $30 \mathrm{~kg} / \mathrm{m}^{2}$, with the range $25-30 \mathrm{~kg} / \mathrm{m}^{2}$ defined as overweight. This is determined by dividing a person's weight by the square of the person's height $\left(\mathrm{kg} / \mathrm{m}^{2}\right)$ [1]. It has been estimated that more than 1 billion adults are overweight globally with more women being commonly obese than men [1]. About 300 million of them are clinically obese. This contributes enormously to the global burden of chronic disease and disability. Obesity is a very complex condition and mostly occurs together with undernutrition with serious social and psychological dimensions, affecting virtually all ages and socioeconomic groups in developing countries [2]. Excessive consumption of more energy dense and poor nutritional foods with high levels of sugar and saturated fats and reduced physical activity including genetic disorders has led to obesity $[1,3]$. Other minor causes of obesity are genes, medications, endocrine abnormality, and mental problem [4]. Previous study has classified obesity as a disease [5]. Obesity epidemic is not restricted to industrialized countries only but greatly multiplies faster in developing countries than in the developed world [2].
However, obesity and overweight are associated with major risk for chronic diseases, including type 2 diabetes mellitus and lipid peroxidation, hypertension, and atherosclerosis. The health implications of these include increased risk of morbidity and mortality such as premature death $[2,6,7]$. In developed countries, the incidence of obesity was reported to correspond to the widespread of diabetes [8]. The frequency of abnormality of lipids, lipoproteins, and apolipoproteins varies in different populations. Lipoprotein abnormalities often precede the onset of diabetes mellitus by many years and persist despite achievement of euglycemia, possibly as a result of increased rates of obesity [8,9]. Lipoprotein abnormalities are common in diabetes and contribute significantly to its complications. The most typical lipoprotein pattern in diabetes, also known as diabetic dyslipidemia or atherogenic dyslipidemia, consists of moderate elevation in triglyceride (TG) levels, low high-density lipoprotein cholesterol (HDLC) values, and small dense low-density lipoprotein (LDL) particles [9]. The present study, therefore, seeks to evaluate the prevalence of obesity and assess the lipid profile and fasting blood glucose (FBG) among the undergraduate female premedical students of Nnamdi Azikiwe University, Nnewi Campus, Nigeria. 


\section{METHODS}

\section{Study design}

This was a cross-sectional study designed to evaluate the prevalence of obesity and assess the FBG level and fasting lipid profile among female undergraduate pre-medical students of the College of Health Sciences, Nnamdi Azikiwe University, Nnewi Campus, Nnewi, Nigeria. The demographic data and medical history were clinically obtained using pre-administered questionnaire. Blood glucose levels and lipid profile were obtained after overnight fasting (12-14 h).

\section{Study population}

A total of 320 undergraduate students aged between 18 and 35 years were recruited for this study using simple random sampling technique. They were categorized using their BMI as underweight (35), overweight (104), and obese (26) participants. The remaining 155 participants were normal (control) participants.

\section{Data collection}

A well-structured questionnaire was administered to all the participants to ascertain their medical history. The height and weight of the subjects were measured. Height was measured to the nearest $0.1 \mathrm{~cm}$ using a tape rule, and weight measured to the nearest $0.1 \mathrm{~kg}$ using calibrated platform scales. The body mass index (BMI) was calculated by the formula of weight $(\mathrm{kg}) /$ height $\left(\mathrm{m}^{2}\right)$.Obesity was assessed using body mass index (BMI) and waist circumference (WC). Based on BMI, the participants were categorized as underweight $\left(<18.5 \mathrm{~kg} / \mathrm{m}^{2}\right)$, normal weight $\left(18.5-24.9 \mathrm{~kg} / \mathrm{m}^{2}\right)$, overweight $\left(25.0-29.9 \mathrm{~kg} / \mathrm{m}^{2}\right)$, and obese $\left(>30.0 \mathrm{~kg}^{2}\right)$ [10]. WC was measured midway between iliac crest and coastal margin. WC cutoff value of $>80 \mathrm{~cm}$ is regarded as risk factor for obesity in females. Three separate blood pressure (BP) readings were obtained per subject from the non-dominant arm using accoson sphygmomanometer with appropriate cuff size in sitting position at 2 min interval after an initial rest of 5-10 min with arm supported at heart level. The average of the past two readings was recorded for both systolic blood pressure and diastolic blood pressures (SBP and DBP) of each student. The cutoff value for hypertension was taken as SBP reading $\geq 130 \mathrm{mmHg}$ and/or DBP of $\geq 85 \mathrm{mmHg}$.

\section{Collection of sample}

Random sampling technique was used during sample collection. Of $7 \mathrm{ml}$ of venous blood collected, $5 \mathrm{ml}$ was dispensed into plain specimen container and allowed to retract, centrifuged and separated for the determination of fasting lipid profile, while remaining $2 \mathrm{ml}$ was dispensed into fluoride oxalate specimen container for FBG level estimation.

\section{Exclusion and inclusion criteria}

Students within the age range of 18-35 years were included in the study. Students who were pregnant, smokers, non-students, students above the age 35, known diabetics, and students with any known form of cardiovascular condition were excluded from the study.

\section{Ethics approval and consent to participate}

All authors hereby declare that all experiment and procedure have been examined and approved by the appropriate board of the Ethics Committee of Nnamdi Azikiwe University Teaching Hospital Nnewi, South East Nigeria, and research have therefore been performed in accordance with the standards laid down in the 1964 Declaration of Helsinki.

\section{Laboratory methods of sample analysis}

Fasting lipid profile test (total cholesterol [TC], TG, HDLC, and LDL cholesterol [LDLC])

TC was determined as described by Trinder [11], while TGs was determined using the method by Tietz [12]. The estimation of HDL was performed using the method as described by Groove [13] and Burstein et al. [14]. This is principally a combination of phosphotungstate precipitation and enzymatic method, while the method of Assman et al. [15] was adopted for LDL. This is a combination of polyvinyl sulfate precipitation and enzymatic method.

\section{FBG estimation}

Glucose oxidase method was used to measure FBG spectrophotometrically as described by Julio and Montola [16].

\section{Statistical analysis}

Statistical analysis was performed using Statistical Package for the Social Sciences version 20. The test of significant difference between the two groups was calculated using the student's t-test with $\mathrm{p}<0.05$. Pearson's correlation coefficient was used to determine the relationship between the lipid profile, FBG, and anthropometric indices.

\section{RESULTS}

\section{Demographic characteristics of study population}

The results showed that of 320 female premedical students recruited for the study, 35 (10.9\%) were underweight, 104 (32.5\%) were overweight, $26(8.1 \%)$ were obese, while $155(48.4 \%)$ were normal participants. The prevalent rate of underweight was higher among participants aged $18-23$ years $(17,48.6 \%)$. Overweight and obesity were more among the age range of 24-29 years of $60(57.7 \%)$ and 14 (53.8\%) participants, respectively. The $\mathrm{WC}$ of overweight and obese participants who were at risk of central obesity was $30(28.8 \%)$ and $8(30.8 \%)$, respectively. They had elevated WC of over $80 \mathrm{~cm} .35$ (33.7\%) overweight and 9 (34.6\%) obese participants had higher SBP, while $30(28.8 \%)$ overweight and $10(38.5 \%)$ obese participants had higher DBP. 10 (28.6\%) underweight participants had lower FBG, while 32 (30.8\%) overweight and 4 (15.4\%) obese participants had higher FBG levels (Table 1).

Comparison (BMI $\left[\mathrm{kg} / \mathrm{m}^{2}\right], W C[\mathrm{~cm}], S B P[\mathrm{mmHg}], \mathrm{DBP}[\mathrm{mmHg}]$, and age) in underweight, overweight, obese, and non-obese (control) female students

The mean BMI in underweight $(18.01 \pm 0.34)$ and overweight (26.81 \pm 0.87$)$ female students was significantly lower compared to obese subjects $(35.69 \pm 1.94)(\mathrm{p}<0.05)$. BMI was significantly higher in overweight $(26.81 \pm 0.87$ and obese $(35.69 \pm 1.94)$ females compared with their corresponding control $(22.34 \pm 1.71)(p<0.05)$. Similar observation was made between underweight $(18.01 \pm 0.34)$ and control $(22.34 \pm 1.71)$ female students. The mean WC was significantly higher in overweight $(82.34 \pm 7.68)$ and obese $(87.08 \pm 8.91)$ compared with underweight $(72.01 \pm 0.23)$ and control $(72.01 \pm 0.23)$ counterparts $(\mathrm{p}<0.05$ respectively). Similarly, WC was significantly higher in obese (87.08 \pm 8.91$)$ compared with the overweight $(82.34 \pm 7.68)$ female students $(\mathrm{p}<0.05)$. The value of SBP in overweight $(132.22 \pm 11.20)$ and obese $(136.48 \pm 14.12)$ female students was significantly higher compared with the value in control females $(115.56 \pm 8.56)(\mathrm{p}<0.05$, respectively), while the value of DBP in overweight (83.76 \pm 8.45 ) and obese female students $(87.89 \pm 11.45)$ was significantly higher when compared with the value in control $(66.83 \pm 7.60)$ counterparts $(p<0.05)$. However, there was no significant difference in the mean age difference of underweight $(25.10 \pm 4.87)$, overweight (24.88 \pm 6.2$)$, and obese $(25.10 \pm 5.34)$ female premedical students when compared with control counterparts $(24.94 \pm 3.35)$ ( $p>0.05$, respectively) (Table 2).

Lipid profile (mmol/l) and FBG (mmol/l) levels in underweight, overweight, obese, and control female students

The mean TC level in overweight $(5.28 \pm 0.86)$ and obese $(5.86 \pm 0.92)$ was significantly higher compared with control $(4.41 \pm 0.84)$ female students $(\mathrm{p}<0.05$, respectively). No significant difference was observed in the value of TC between underweight $(4.05 \pm 0.25)$ and control $(4.41 \pm 0.84)$ female students $(\mathrm{p}<0.05)$.

However, the mean HDLC in overweight $(1.07 \pm 0.29)$ and obese $(0.89 \pm 0.17)$ female students was significantly lower compared with underweight $(1.46 \pm 0.43)$ and control $(1.44 \pm 0.56)$ counterparts $(\mathrm{p}<0.05$ respectively). No significant difference was observed in HDL level 
Table 1: Demographic characteristics of the study population

\begin{tabular}{|c|c|c|c|c|}
\hline BMI parameters & $\begin{array}{l}\text { Underweight }(<18.5) \text { F \% } \\
n=35,10.9\end{array}$ & $\begin{array}{l}\text { Overweight (25-29.9) F \% } \\
\mathrm{n}=104,32.5\end{array}$ & $\begin{array}{l}\text { Obese }(>30) \text { F } \% \\
n=26,8.1\end{array}$ & $\begin{array}{l}\text { Normotensive (18.5-24.9) F \% } \\
\mathrm{n}=155,48.4\end{array}$ \\
\hline \multicolumn{5}{|l|}{ Age } \\
\hline $18-23$ & $17(48.6)$ & $25(24.2)$ & $8(19.2)$ & $79(50.9)$ \\
\hline $24-29$ & $12(34.3)$ & $60(57.7)$ & $14(58.8)$ & $40(25.8)$ \\
\hline $30-34$ & $6(17.1)$ & $19(18.3)$ & 7 (26.9) & $36(23.2)$ \\
\hline \multicolumn{5}{|l|}{ WC } \\
\hline Normal & 35 (100) & $74(71.2)$ & $18(69.2)$ & 135 (87.1) \\
\hline At risk & $0(0)$ & $30(28.8)$ & $8(30.8)$ & 20 (12.9) \\
\hline \multicolumn{5}{|l|}{ SBP } \\
\hline Normal & $33(94.3)$ & 55 (52.9) & $16(61.5)$ & $146(94.2)$ \\
\hline Low & $1(2.8)$ & 14 (13.5) & $1(3.8)$ & $1(0.6)$ \\
\hline High & $1(2.8)$ & 35 (33.7) & $9(34.6)$ & $8(5.2)$ \\
\hline \multicolumn{5}{|l|}{ DBP } \\
\hline Normal & 35 (100) & $62(59.6)$ & $14(53.8)$ & 151 (97.4) \\
\hline Low & $0(0)$ & $12(11.5)$ & $2(7.7)$ & $1(0.06)$ \\
\hline High & $0(0)$ & $30(28.8)$ & $10(38.5)$ & 3 (1.9) \\
\hline \multicolumn{5}{|l|}{ FBG } \\
\hline Normal & 25 (71.4) & $70(67.3)$ & $22(84.6)$ & $140(90.3)$ \\
\hline Low & $10(28.6)$ & $2(1.9)$ & $0(0)$ & $13(8.4)$ \\
\hline High & $0(0)$ & $32(30.8)$ & $4(15.4)$ & $2(1.3)$ \\
\hline
\end{tabular}

BMI: Basal metabolic index, F: Frequency, \%: Percentage, n: Number. FBG: Fasting blood glucose, WC: Waist circumference, SBP: Systolic blood pressure, DBP: Diastolic blood pressures

Table 2: Comparison of mean $( \pm S D)$ BMI $\left(\mathrm{kg} / \mathrm{m}^{2}\right), \mathrm{WC}(\mathrm{cm}), \mathrm{SBP}, \mathrm{DBP}$, and age in underweight, overweight, obese, and normotensive (control) female premedical students

\begin{tabular}{|c|c|c|c|c|c|}
\hline Groups & BMI & WC & SBP & DBP & Age \\
\hline Underweight $(A)(n=30)$ & $18.01 \pm 0 . S 34$ & $72.01 \pm 0.23$ & $101.28 \pm 9.94$ & $68.24 \pm 6.76$ & $25.01 \pm 4.87$ \\
\hline Overweight $(B)(n=104)$ & $26.81 \pm 0.87$ & $82.34 \pm 7.68$ & $132.12 \pm 11.20$ & $83.76 \pm 8.45$ & $24.88 \pm 6.20$ \\
\hline Obese $(C)(n=31)$ & $35.69 \pm 1.94$ & $87.08 \pm 8.91$ & $136.48 \pm 14.12$ & $87.89 \pm 11.45$ & $25.10 \pm 5.34$ \\
\hline Normotensive (D) $(n=155)$ & $22.34 \pm 1.71$ & $76.59 \pm 2.74$ & $115.56 \pm 8.56$ & $66.83 \pm 7.60$ & $24.94 \pm 3.35$ \\
\hline F-value & 4.194 & -4.620 & 36.194 & 32.839 & 0.062 \\
\hline p-value & 0.000 & 0.000 & 0.000 & 0.013 & 0.912 \\
\hline A vs. B & 0.000 & 0.001 & 0.093 & 0.006 & 0.741 \\
\hline A vs. D & 0.030 & 0.020 & 0.372 & 0.472 & 0.528 \\
\hline B vs. C & 0.000 & 0.041 & 0.062 & 0.157 & 0.448 \\
\hline B vs. D & 0.042 & 0.003 & 0.000 & 0.000 & 0.895 \\
\hline C vs. D & 0.000 & 0.000 & 0.000 & 0.001 & 0.375 \\
\hline
\end{tabular}

SBP: Systolic blood pressure, DBP: Diastolic blood pressure, WC: Waist circumference, BMI: Basal metabolic index, SD: Standard deviation

between underweight $(1.46 \pm 0.43)$ and control $(1.44 \pm 0.56)$ females ( $p>0.05)$ and between overweight $(1.07 \pm 0.29)$ and obese $(0.89 \pm 0.17)$ counterparts $(\mathrm{p}>0.05)$.

LDLC level in overweight (3.46 \pm 0.58$)$ and obese (4.26 \pm 0.84$)$ female students was significantly higher compared with their corresponding values in underweight $(3.01 \pm 0.31)$ and control $(3.18 \pm 0.49)$ females $(\mathrm{p}<0.05$, respectively). No significant difference existed between underweight $(3.01 \pm 0.31)$ and control $(3.18 \pm 0.49)$ females $(p>0.05)$. Contrastingly, the mean LDLC level was significantly lower in overweight $(3.46 \pm 0.58)$ compared obese $(4.26 \pm 0.84)$ female students $(\mathrm{p}<0.05)$.

The mean TG level in underweight $(1.11 \pm 0.45)$, overweight $(1.21 \pm 0.64)$, and obese $(1.25 \pm 0.84)$ female students was not significantly different from control $(1.19 \pm 0.39)$ counterparts $(\mathrm{p}>0.05$, respectively).

The mean FBG level in overweight $(5.01 \pm 0.29)$ and obese $(5.12 \pm 0.38)$ was significantly higher compared with the values in underweight $(4.72 \pm 0.36)$ and control $(4.83 \pm 0.32)$ female students $(p<0.05)$. On the other hand, no significant difference was existed between underweight $(4.72 \pm 0.36)$ and control $(4.83 \pm 0.32)$ female students $(p>0.05)$ (Table 3$)$.

Pearson correlation of lipid profile ( $\mathrm{mmol} / \mathrm{l}), \mathrm{FBG}$ (mmol/l), and anthropometric parameters in overweight and obese participants Significant positive correlation was observed between TC and age, FBG; TG and age, FBG, WC; LDL and FBS; HDL and age while significant negative correlation existed between TC and BMI, SBP, DBP; TG and BMI; HDL and BMI, WC in both overweight and obese participants.

\section{DISCUSSION}

The present study recorded $10.9 \%$ underweight, $32.5 \%$ overweight, and $8.1 \%$ obesity among all the study population. Underweight was more common among students whose age ranged 18-23 years. The high incidence of underweight among university students has been previously reported $[17,18]$. The overall implications of this include malnutrition, menstrual irregularities, diabetes, osteoporosis, and reduced immunity [19-21]. The prevalence of underweight recorded among these students may be attributed not only to poor feeding habits but also to misperceptions usually exhibited by these female students that they want to maintain a good shape. Most of the students under this age range might be newly admitted students who have not become acquainted with university environment and their feeding habits $[17,22-25]$. The overweight and obesity were more prevalent in female premedical undergraduate students between the age range of 24 and 29 years although overweight was higher than obese participants. This is in agreement with study by Oguoma et al. [21,26]. Similarly, SBP, DBP, WC, and FBG were all elevated in overweight and obese students when compared with control participants. These findings indicate that the overweight students were at the verge of getting to obesity, central obesity, hypertension, and pre-diabetes which might result to future cardiovascular diseases if the risk factors 
Table 3: Mean $( \pm \mathrm{SD})$ levels of lipid profile $(\mathrm{mmol} / \mathrm{l})$ and FBG $(\mathrm{mmol} / \mathrm{l})$ in underweight, overweight, obese, and control female premedical students

\begin{tabular}{|c|c|c|c|c|c|}
\hline Groups & TC & HDL & LDL & TG & FBG \\
\hline Underweight (A) $(n=30)$ & $4.05 \pm 0.25$ & $1.46 \pm 0.43$ & $3.01 \pm 0.31$ & $1.11 \pm 0.45$ & $4.72 \pm 0.36$ \\
\hline Overweight $(B)(n=104)$ & $5.28 \pm 0.86$ & $1.07 \pm 0.29$ & $3.46 \pm 0.58$ & $1.21 \pm 0.64$ & $5.01 \pm 0.29$ \\
\hline Obese (C) $(n=31)$ & $5.86 \pm 0.92$ & $0.89 \pm 0.17$ & $4.26 \pm 0.84$ & $1.25 \pm 0.84$ & $5.12 \pm 0.38$ \\
\hline Normotensive (D) $(n=155)$ & $4.41 \pm 0.84$ & $1.44 \pm 0.56$ & $3.18 \pm 0.49$ & $1.19 \pm 0.39$ & $4.83 \pm 0.32$ \\
\hline F-value & 0.395 & 0.446 & 0.341 & 0.058 & 0.059 \\
\hline p-value & 0.007 & 0.002 & 0.000 & 0.106 & 0.010 \\
\hline A vs. B & 0.000 & 0.000 & 0.000 & 0.863 & 0.029 \\
\hline A vs. D & 0.063 & 0.873 & 0.811 & 0.360 & 0.741 \\
\hline B vs. C & 0.046 & 0.058 & 0.000 & 0.673 & 0.692 \\
\hline B vs. D & 0.000 & 0.003 & 0.010 & 0.773 & 0.000 \\
\hline C vs. D & 0.001 & 0.000 & 0.000 & 0.315 & 0.006 \\
\hline
\end{tabular}

TC: Total cholesterol, HDL: High-density lipoprotein, LDL: Low-density lipoprotein, TG: Triglycerides, FBG: Fasting blood glucose, SD: Standard deviation

Table 4: Correlation of lipid profile (mmol/l), FBG (mmol/l), and anthropometric indices in overweight and obese female subjects

\begin{tabular}{llll}
\hline Parameters & overweight R & obese R & p-value \\
\hline TC vs. BMI & -0.353 & -0.256 & $<0.005$ \\
TC vs. age & 0.453 & 0.589 & $<0.005$ \\
TC vs. SBP & -0.311 & -0.456 & $<0.005$ \\
TC vs. DBP & -0.401 & -0.442 & $<0.005$ \\
TC vs. FBG & 0.383 & 0.399 & $<0.005$ \\
TG vs. BMI & -0.438 & -0.438 & $<0.005$ \\
TG vs. FBS & 0.428 & 0.297 & $<0.005$ \\
TG vs. age & 0.399 & 0.382 & $<0.005$ \\
TG vs. WC & 0.275 & 0.288 & $<0.005$ \\
LDL vs. FBG & 0.311 & 0.344 & $<0.005$ \\
HDL vs. BMI & -0.714 & -0.789 & $<0.005$ \\
HDL. vs. age & 0.663 & 0.796 & $<0.005$ \\
HDL vs. WC & -0.221 & -0.256 & $<0.005$ \\
\hline
\end{tabular}

TC: Total cholesterol, HDL: High-density lipoprotein, LDL: Low-density lipoprotein, TG: Triglycerides, SBP: Systolic blood pressure, DBP: Diastolic blood pressure, WC: Waist circumference, BMI: Basal metabolic index, FBG: Fasting blood glucose

are not controlled on time. Increased morbidity and mortality rate as a result of increase in cardiovascular diseases have been grossly reported in developing countries including Nigeria $[27,28]$. This may be attributed to the westernized lifestyle and physical inactivity among these participants $[18,29]$. The westernized lifestyle is as a result of frequent consumption of saturated fats, poor and unhealthy fast foods such as snacks, and indomie by university students. High incidence of overweight and obesity among female undergraduate students has been widely reported [25,30-32]. Our study has shown the presence of higher prevalence rate of central obesity in overweight as well as obese participants. This is consistent with the study reported by Ogunmola et al. [33] and Adegoke et al. [34]. The authors reported that in addition to unhealthy eating and physical inactivity, urbanization was also a factor. Excessive consumption of high calorie carbohydrate junk food [1,3] and saturated unprocessed palm fruit soup popularly known as "OfeAkwu" which is common and frequently consumed by students in this locality may also contribute greatly to the increase and accumulation of high amount of calorie and can result to the condition observed in this study. Reports have shown that central obesity is associated with cancer, heart diseases as well as lipid dysregulation and these can greatly contribute to risk of cardiovascular disorders $[35,36]$. The significant elevation in blood pressure among overweight and obese participants in this study suggests that these students might be predisposed to hypertension if appropriate intervention is not instituted. Previous reports have been documented $[37,38]$. There have been strong reports on significant association between obesity and hypertension in young adults [39-41]. It has also been established that lipid abnormality even in apparently normal subjects might result to hypertension [42].
The present study showed that TC, LDL, and FBG were significantly higher in overweight and obese participants when compared with normal participants. However, no significant difference was observed in TG level between the obese and control counterparts. High levels of fats and TC are potential risk factors for developing macrovascular complications such as coronary heart disease (CHD) and stroke [21,43-45]. Serum TC ranging from 5.0 to $6.5 \mathrm{mmol} / \mathrm{L}$ has been established as risk factor for CHD and considered undesirable [46]. Obesity is the leading cause of dyslipidemia (abnormal lipid concentrations) and diabetes mellitus. Dyslipidemia, on the other hand, has been associated with CHD which can be caused by elevated levels of TGs, TC, and LDLC [47]

Normal LDLC concentration has been established to be $<130 \mathrm{mg} / \mathrm{dl}$ (3.36 mmol/L). Concentrations higher than $160 \mathrm{mg} / \mathrm{dl}$ (4.14 mmol/L) are considered high risk [47]. The findings in the present study showed that the obese participants were at high risk of developing cardiovascular disease which may be as result of oxidative modification of LDLC or other environmental factors such as lack of exercise and increased intake of junk foods with poor nutrients. Previous reports have shown that high levels of LDLC are an indication of progression to atherosclerosis which is a known risk of cardiovascular disorders, thus the major causes of morbidity and mortality [48].

Our study observed significantly lower level of HDL in obese subjects when compared with the value control participants. This is in agreement with the findings by Després [49] and Kimberly et al. [50]. Abnormal HDLC might be a leading cause of atherogenic dyslipidemia. Furthermore, the previous report has shown that a low level of highdensity lipoprotein cholesterol is consistent with atherosclerosis [51]. Furthermore, low HDL levels in obese subjects can contribute greatly to the risk of cardiovascular diseases. HDL is known as the "good cholesterol" which helps to mop up cholesterol, removes extra cholesterol from the peripheral tissues, and transports it to the liver for degradation and storage [51]. HDLC possesses a potent antiinflammatory and antioxidant effects which can prevent the atherogenic process $[52,53]$.

The significantly higher FBG level observed in overweight and obese participants in the present study is consistent with the study done by McGill et al. [54] even though the increase was not higher than the reference range. The authors reported that obese subjects with elevated FBG are prone to diabetes mellitus. Individuals with FBG ranging from 110 to $125 \mathrm{mg} / \mathrm{dl}$ have been postulated to have a double to 6-fold increase of developing diabetes mellitus [55]. These participants if the risk factors of obesity are not controlled may be predisposed to diabetes. Studies in Nigeria have documented the high incidence of impaired fasting glucose as well as impaired glucose tolerance [56-58]. Elevated glucose levels in the intermediate range are caused primarily by a deficiency in insulin secreted by pancreatic beta cells. Deficient insulin secretion can be caused by loss of beta cells or defect in the function of beta cell $[59,60]$. 
An elevated glucose level is one major characteristic that can define metabolic syndrome. Others are abdominal obesity, elevated blood pressure, elevated TGs, and reduced HDL cholesterol. Any 3 of these 5 conditions can establish the diagnosis of the syndrome [61,62]. However, the obese students, in this study, presented with similar findings showing possible development to pre-diabetes as well as metabolic syndrome if the obesity is not checked. Significant number of individuals with metabolic syndrome has abdominal obesity. Increased storage of fatty acids in the adipose tissue can lead to excessive release of adipokines. This can encourage metabolic susceptibility to diabetes and cardiovascular disease [63].

Significant positive correlation were observed between TC, HDL, TG and age, FBG while significant negative correlation existed between TC, HDL, TG and BMI, SBP DBP, WC respectively in overweight and obese participants. Similar reports have been previously documented $[45,54,64-66]$. Evidence has also shown that FBG positively correlated with BMI [67]. Adequate physical exercise increases the activation of the peptide hormone adiponectin that causes the cascade activation of activated protein kinase to prevent the syntheses of malonyl-coenzyme A ( $\mathrm{CoA}$ ) for fatty acid biosynthesis in hepatocytes by acetyl CoA carboxylase [67]. This enhances the uptake of glucose and fatty acid from the blood myocytes into the hepatocytes for metabolism $[68,69]$. The increased accumulation of weight by the female in the present study may also be attributed to creeping weight normally accumulated after sensitization of ghrelin hormone which enhances the hunger reflexes in females after strenuous activities. Females tend to relax after dietary intake, thereby resulting to increase in weight gain [70]. The significant association between lipid parameters and anthropometric indices in the present study might be attributed to risk factors for dyslipidemia, hypertension, and obesity [71]. Previous reports have shown that lipid abnormality even in normal subjects might result to hypertension and can enhance the risk of developing macrovascular complications [42,72]. Abnormal HDLC can result in endothelial damage and trigger an increase in BP; this might significantly contribute to CHD. Report has shown that low HDLC level of $1 \mathrm{mg} / \mathrm{dL}(0.03 \mathrm{mmol} / \mathrm{L})$ can result to risk of CHD in both men and women. Therefore, a low HDLC level of $\leq 40 \mathrm{mg} / \mathrm{dL}(\leq 1.04 \mathrm{mmol} / \mathrm{L})$ was established as undesirable for both genders $[73,74]$ and should be regarded as a baseline for treatment to reduce cardiovascular risk.

\section{CONCLUSION}

The present study showed significantly higher levels of TC, LDLC, and FBG in overweight and obese female participants with significantly lower HDLC when compared to controls. The lipid parameters were significantly correlated with the anthropometric indices, suggesting that the study participants have high potentials for developing cardiovascular risk factors such as dyslipidemia, hypertension, and obesity. However, this study justifies the need to encourage modalities and appropriate interventions to promote healthy body mass, frequent physical activities, and high calorie dietary controls with quality protein foods and fruits to prevent or minimize risks of developing disorders associated with obesity among the study population. A more longitudinal study is also advocated in the study environment, male student inclusive, to ascertain a clearer picture of overweight and obesity status among these individuals to cub the increase and future menace of cardiovascular disease among this young population.

\section{ACKNOWEDGMENTS}

We are immensely grateful to all the female premedical students of Nnamdi Azikiwe University, Nnewi Campus, Anambra State, Nigeria, for giving us their informed consent to use their sample for analysis.

\section{AUTHORS' CONTRIBUTION}

1. Conceptualization and study design - Nkiruka Rose Ukibe and Solomon Nwabueze Ukibe.

2. Data collection, sample analysis, and performing the experiment - Nkiruka Rose Ukibe, Emmanuel Ikechukwu Onwubuya, and Ofia Anya Kalu.
3. Preparation of manuscript - Nkiruka Rose Ukibe, Solomon Nwabueze Ukibe, and Ifeoma Nwamaka Monago.

4. Statistical Analysis - Ofia Anya Kalu and Obiageli Fidelia Emelumadu.

5. Proofreading the manuscript - Solomon Nwabueze Ukibe, Emmanuel Ikechukwu Onwubuya, and Obiageli Fidelia Emelumadu.

6. All authors read and approved the final manuscript.

\section{CONFLICTS OF INTEREST}

All authors have none to declare.

\section{REFERENCES}

1. World Health Organization. Obesity and Overweight. Fact Sheet; 2016.

2. World Health Organization. Global Strategy on Diet, Physical Inactivity and Health. Geneva: World Health Organization; 2003.

3. Yazdi FT, Clee SM, Meyre D. Obesity genetics in mouse and human: Back and forth, and back again. Peer J 2015;3:e856.

4. Bleich SN. Public perception of overweight. BMJ 2008;337:A347.

5. Andrew P. A.M.A. Recognizes Obesity As a Disease. New York Times 19 Jun. 2013: B.1. SIRS Issues Researcher. Web. 01 May. 2014.

6. Matthew W. The Facts about Obesity. H\&HN. American Hospital Association; 2013. p. 5.

7. Finkelstein EA,Trogdon JG, Cohen JW, Dietz W. Annual medical spending attributable to obesity: Payer-and service-specific estimates. Health Aff 2009;28:W822-31.

8. Abhay KP, Deepti P, Abha P. Obesity and lipid profile study in Type 2 diabetes patients with auditory and reaction time deficits and nondiabetic control subjects. Adv Diabetes Metab 2017:5:1-5.

9. Khalid SJ, Aljabri AS, Bokhari AA. The relation between overweight, obesity and plasma lipids in Saudi adults with Type 2 diabetes. J Health Spec 2016;4:140-5.

10. World Health Organization. Obesity: Preventing and Managing. The Global Epidemic. Report of a WHO Consultation. Geneva: WHO Technical Report Series 894; 2000. p. 252.

11. Trinder P. Determination of blood glucose using an oxidase-peroxidase system. J Clin Pathol 1969;22:158-61.

12. Tietz NW, Finley PR, Pruden EL. Clinical Guide to Laboratory Tests. $2^{\text {nd }}$ ed. Philadelphia, PA: W.B. Saunders; 1990. p. 304-6.

13. Groove TH. Effect of Reagent $\mathrm{pH}$ on the determination of High density lipoprotein cholesterol by precipitation with sodium phosphotungstate magnesium. Clin Chem 1979;25:560-4.

14. Burstein M, Scholnick HR, Morfin R. Rapid method for the isolation of lipoproteins from serum by precipitation with polyanions. Scand J Clin Lab Invest 1980;40:583-95.

15. Assman G, Jabs HU, Kohnert U, Nolte W, Schriewer H. LDL cholesterol determination in blood serum following precipitation of LDL with polyvinyl sulphate. J Anal Chim Acta 1984;140:77-83.

16. Julio R, Mottola HA. Glucose Oxidase as an Analytical Reagent. J Crit Rev Anal Chem 1995;25:1-42.

17. Sirang Z, Bashir HH, Jalil B, Khan SH, Hussain SA, Baig A, et al. Weight patterns and perceptions among female university students of Karachi: A cross sectional study. BMC Public Health 2013;13:230.

18. Anandhasayanam A, Jimshad MI, Kannan S, Johnson JS, Chander U. Perception of paramedical students in a teaching institute on BMI, diet and social habits-a cross sectional survey. Int J Pharm Pharm Sci 2015;7:226-31.

19. Montero P, Bernis C, Fernandez V, Castro S. Influence of body mass index and slimming habits on menstrual pain and cycle irregularity. J Biosoc Sci 1996;28:315-23.

20. Black RE, Morris SS, Bryce J. Where and why are 10 million children dying every year? Lancet 2003;361:2226-34.

21. Begum KS, Kavuri NS, Uppalapati MC, Polavarapu D. Assessment of the nutritional behaviour among college students-a survey. Int J Pharm PharmSci 2018;10:46-9.

22. Chumlea WC, Guo SS. Body mass and bone mineral quality. Curr Opin Rheumatol 1999;11:307-11.

23. Brener ND, Eaton DK, Lowry R. The association between weight perception and BMI among high school students. Obes Res 2004:12:1866-74.

24. Wharton CM, Adams T, Hampl JS. Weight loss practices and body weight perceptions among US college students. J Am Coll Health 2008;56:579-84.

25. Ukegbu PO, Uwaegbute PO, Echendu CA, Ejike C, Anyika-Elekeh JU, Asumugha $\mathrm{VU}$, et al. Obesity and associated factors in young adults attending tertiary institutions in south-eastern Nigeria. S Afr J ClinNutr 
2017;30:43-8

26. Oguoma VM, Nwose EU, Skinner TC, Digban KD, Onyia IC, Richards RS. Prevalence of cardiovascular disease risk factors among a Nigerian adult population: relationship with income level and accessibility to CVD risks screening. BMC Public Health 2015;15:397.

27. The World Health Report: Reducing Risks, Promoting Healthy Lifestyles. Geneva: World Health Organization; 2002.

28. Lopez AD, Mathers CD, Ezzati M, Jamison DT, Murray CJ. Global and regional burden of disease and risk factors, 2001: Systematic analysis of population health data. Lancet 2006;367:1747-57.

29. Kelishadi R, Alikhani S, Delavari A, Alaedini F, Safaie A, Hojatzadeh E. Obesity and associated lifestyle behaviors in Iran: Findings from the first national non-communicable disease risk factor surveillance survey. Public Health Nutr 2008;11:246-51.

30. Mogre V, Aleyira S, Nyaba R. Factors associated with central overweight and obesity in students attending the University for development studies in Tamale, Ghana: A cross-sectional study. S Afr J Clin Nutr 2014;27:69-74

31. Peltzer K, Pengpid S, Samuels TA, Özcan NK, Mantilla C, Rahamefy $\mathrm{OH}$, et al. Prevalence of overweight/obesity and its associated factors among university students from 22 countries. Int J Environ Res Public Health 2014;11:7425-41

32. Chinedu SN, Emiloju OC. Underweight, overweight and obesity amongst young adults in Ota. Nigeria. J Publ Health Epidemiol 2014;6:235-8

33. Ogunmola OJ, Olaifa AO, Oladapo OO, Babatunde OA. Prevalence of cardiovascular risk factors among adults without obvious cardiovascular disease in a rural community in Ekiti State Southwest Nigeria. BMC Cardiovas Disorders 2013;13:89.

34. Adegoke OA, Adedoyin RA, Balogun MO, Adebayo RA, Bisiriyu LA, Salawu AA. Prevalence of metabolic syndrome in a rural community in Nigeria. Metab Syndr Relat Disord 2010;8:59-62.

35. Westphal S, Orth M, Ambrosch A. Postprandial chylomicrons and VLDLs in severe hypertriacylglycerolemia are lowered more effectively than are chylomicron remnants after treatment with n-3 fatty acids. Am J Clin Nutr 2000;71:914-92.

36. Després JP, Lemieux I. Abdominal obesity and metabolic syndrome. Nature 2006;444:881-7.

37. Ejike CE, Ugwu CE, Ezeanyika LU. Variations in the prevalence of point (pre)hypertension in a Nigerian school-going adolescent population living in a semi-urban and an urban area. BMC Pediatr 2010;10:13.

38. Ejike CE, Ugwu CE. Association between blood pressure and urinary electrolytes in a population of nonurban-dwelling Nigerians. Nig J Clin Pract 2012;15:258-64.

39. Ross R. The pathogenesis of atherosclerosis: A perspective for the 1990s. Nature 1993;362:801-9.

40. Qiao Q, Gao W, Zhang L, Nyamdorj R, Tuomilehto J. Metabolic syndrome and cardiovascular disease. Ann Clin Biochem 2007;44:232-63.

41. Okafor C, Anyaehie U, Ofoegbu E. The magnitude of obesity and its relationship to blood pressure among the residents of Enugu metropolis in South East Nigeria. Ann Med Health Sci Res 2014;4:624

42. Halperin RO, Sesso HD, Ma J, Buring JE, Stampfer MJ, Gaziano JM. Dyslipidemia and the risk of incident hypertension in men. Hypertens 2006; 47:45-50.

43. Gaziano JM, Hennekens CH, O’Donnell CJ, Breslow JL, Burring JE. Fasting triglycerides, high-density lipoprotein, and risk of myocardial infarction. Circulation 1997;96:2520-25.

44. Albucher JF, Ferrieres J, Ruidavets JB, Guiraud-Chaumeil B, Perret BP, Chollet F. Serum lipids in young patients with ischaemic stroke: A casecontrol study. J Neurol Neurosurg Psych 2000;69:29-33.

45. Onat A, Sari I, Yazici M, Can G, Hergenc G, Avci GS. Plasma triglycerides, an independent predictor of cardiovascular disease in men: A prospective study based on a population with prevalent metabolic syndrome. Int J Cardiol 2006;108:89-95.

46. Lewis B. The appropriate use of diagnostic services: (viii) the investigation of hyperlipidaemia: Why, how and for whom? Health Trends 1986;18:1-4

47. Bachorik PS, Ross JW. National cholesterol education programme recommendations for measurement of low-density lipoprotein cholesterol: Executive summary. The national cholesterol education program working group on lipoprotein measurement. Clin Chem 1995;41:1414-20.

48. Hansson GK, Hermansson A. The immune system in atherosclerosis.
Nat Immunol 2011;12:204-12.

49. Després JP, Lemieux, Dagenais GR, Cantin B, Lamarche B. HDLcholesterol as a marker of coronary heart disease risk: The Québec cardiovascular study. Atherosclerosis 2000;153:263-72.

50. Kimberly AE, Timothy SM, Hao W, Nathalie P, Barbara AH, Mark TC. Obesity and weight loss result in increased adipose tissue ABCG1 expression in db/db mice. Biochem Biophys 2012;1821:425-34.

51. Jialal, I. Evolving lipoprotein risk factors: Lipoprotein (a) and oxidized low-density lipoprotein. Clin Chem 1998;44:1827-32.

52. Barter PJ, Rye KS, Anantharamaiah GM, Navab M, Fogelman AM. Anti-inflammatory properties of HDL. Circ Res 2004;95:764-72.

53. Mackness MI, Durrington PN, Mackness B. How high-density lipoprotein protects against the effects of lipid peroxidation. Curr Opin Lipidol 2000;11:383-8.

54. McGill HCJ, McMahan CA, Herderich EE, Zieshe AW, Malcom GT, Tracy RE. Obesity accelerates the progression of coronary atherosclerosis in young men. Circulation 2002;105:2712-18.

55. World Health Organization. Definition and Diagnosis of Diabetes Mellitus and Intermediate Hyperglycaemia. Geneva: Report of a WHO/ IDF Consultation; 2006

56. Huang TT, Shimel A, Lee RE, Delancey W, Strother ML. Metabolic risks among college students: Prevalence and gender differences. Metab Syndr Relat Disord 2007;5:365-72.

57. American Diabetes Association. Standards of medical care in diabetes. Diabetes Care 2009;27:515.

58. Nwatu CB, Ofoegbu EN, Unachukwu CN, Young, Okafor CI, Okoli CE. The Prevalence of Prediabetes and Associated risk Factors in a Rural Nigerian Community. Nigeria: International Journal of Diabetes in Developing Countries; 2015

59. Rhodes CJ. Type 2 diabetes - a matter of b-cell life and death? Science 2005;307:380-3

60. Ferrannini E, Gastaldelli A, Iozzo P. Pathophysiology of prediabetes. Med Clin Northern Am 2011;95:327-39.

61. Janghorbain M, Hedley AJ, Jones RB. Is the association between glucose levels and "all causes" and cardiovascular mortality risk, dependent on body mass index? Met J IR I 1991;6:205-12.

62. Grundy SM, Cleeman JI, Daniels SR, Donato KA, Eckel RH, Franklin BA, et al. Diagnosis and management of the metabolic syndrome: An American heart association/national heart, Lung, and blood institute scientific statement. Circulation 2005;112:2735-52.

63. Deng Y, Scherer PE. Adipokines as novel biomarkers and regulators of the metabolic syndrome Ann N Y Acad Sci 2010;1212:E1-E19.

64. Akpa MR, Agomouh DI, Alasia DD. Lipid profile of healthy adult Nigerians in Port Harcourt, Nigeria. Niger J Med 2006; 15:137-40.

65. Hajian-Tilaki KO, Heidari B. Prevalence of obesity, central obesity and the associated factors in urban population aged 20-70 years, in the north of Iran: A population-based study and regression approach. Obes Rev 2007;8:3-10

66. Alikhani RS, Delavari A, Alaedini F, Safaie A, Hojatzadeh E. Obesity and associated lifestyle behaviours in Iran: Findings from the first national non-communicable disease risk factor surveillance survey. Public Health Nutr 2008;11:246-51.

67. Need AG, O'Loughlin PD, Horowitz M, Nordin BE. Relationship between fasting serum glucose, age, body mass index and serum 25 hydroxyvitamin D in postmenopausal women Clin Endocrinol (Oxf) 2005;62:738-41.

68. Braun B, Zimmermann MB, Kretchmer N. Effects of exercise intensity on insulin sensitivity in women with non-insulindependent diabetes mellitus. J Appl Physiol 1995,78:300-6.

69. Henriksson J. Influence of exercise on insulin sensitivity. J Cardiovasc Risk 1995;2:303-9.

70. Adam TC, Epel ES. Stress, eating and the reward system. Physiol Behav 2007;91:449-58.

71. Pelkonen R, Nikkila EA, Koskinen S. Association of serum lipids and obesity with cardiovascular mortality. Br Med J 1977;2:1185-7.

72. Pavithran $P$, Nandeesha $H$, Madanmohan. Dyslipidemia antedates occurrence of clinical hypertension in non-diabetic, non-obese male subjects. Indian J Physiol Pharmacol 2007;51:96-8.

73. Gordon DJ, Probstfield JL, Garrison RJ. High-density lipoprotein cholesterol and cardiovascular disease. Four prospective American studies. Circulation 1989;79:8-15.

74. The Accord Study Group. Effects of combination lipid therapy in Type 2 diabetes mellitus.N Engl J Med 2010;362:1563-74. 